\title{
SPIRITUAL WELL-BEING
}

Nadezhda D. Tvorogova

I.M. Sechenov First Moscow State Medical University

Moscow

\begin{abstract}
The article considers the role of personal and social values in the regulation of human behaviour. These values could be unconscious and hiding behind habits and rules, patterns of behaviour and thinking, but they can be realized by both an individual and social community and eventually their choice in this case which arises an opportunity to make them manageable. Consideration of the spiritual component of public health has led the author of this article to discuss the concepts of "spiritual well-being" and "spiritual diseases". The article contains data of empirical research of deviant behaviour as a consequence of spiritual distress.
\end{abstract}

Keywords: social values, behaviour, spiritual well-being.

\section{Values that regulate social behaviour}

“The United Nations Millennium Declaration" adopted by the General Assembly Summit which was held on September 6-8, 2000 (Session 55 , paragraph $60 \mathrm{~b}$ of the agenda) includes the list of basic objectives that the UN gives special importance. The Declaration starts with the statement of those values and principles that are followed by the heads of state and government at the dawn of the new millennium. Why are these values given so much significance?

It is a well-known psychological fact that activity of a biological creature or a social institution is triggered by its needs. However, behaviour of both human individuals and social communities is regulated not only by a set of patterns, but also by human values and attitudes. These values and attitudes may be unconscious and hiding behind habits and rules, behavioural patterns and a way of thinking, but they can be realized by both individual and social community who have an opportunity to make them manageable. The choice of values is the manifestation of both freedom and responsibility. Making a conscious choice about values which regulate his/her social behaviour a human individual becomes a true 
citizen with all the personal, social (e.g. economic, legal, etc.) attributes (Ball, 1997).

The system of values accepted in society gives rise to beliefs, principles, social attitudes and norms, personal and social behavioural goals, and also regulates the decision making process at all stages of social activity. Any change in the system of values leads to significant changes in social behaviour projects as a way of behaviour modification.

Throughout human history, there have been dreams about building a society regulated by human values that could promote not only its economic, but also its intellectual and ethical development. Such dreams about the people, state, professional communities managed by true noble people, aristocrats of the spirit would remain an empty dream even today, but for scientific research data of the recent decades which indicate that cultural values do influence successful functioning of human communities and their economy.

Why do some ethnic groups and nations live better off than other ones of the kind? The determining factors include the climate, the geographical location, the size of the country, natural resources, the choice of policies, and good management, etc.

However, according to Daniel P. Moynihan ("The New Republic", June 7,1986 ) it is culture but not politics that determines the success of society. The author believes that some cultural values may hinder economic development while the others may be really beneficial for it. In 1985, Lawrence E. Harrison published his book "Underdevelopment Is a State of Mind - The Latin American Case", in which the notion of culture is defined as a coherent system of values, attitudes and institutions that influence individual and social behaviour.

\section{Spirituality and spiritual development}

Psychologists and physicians have lately become closer to peer into the spiritual aspect of a human being.

Nowadays basic approaches to studying spirituality are as follows: (1) spirituality as a principle of self-development and self-actualization; (2) the roots of spirituality, which do not go deeply into a human individual (especially in his/her personal traits or tendency to reflection), but also in his/her creative activity and in the products of life; (3) study of the factors of human spiritual states; (4) religious studies. 
Self-reflection ("What is my true essence? Who am I?") is accompanied by the search for the meaning of life, while specific life events are given a specific value. This "spiritual work" contributes to personal growth. Each person has to make an individual choice among a wide range of values and assign them to regulating personal behaviour, the daily exercise of this choice being a test of his/her personality. A person has an opportunity to make a voluntary conscious choice to follow his/ her spiritual path.

Spiritual life evolves not only self-determination, the choice of guidelines, strong-willed volunteer orientation for these or other human values, but also implementation of these values in everyday life. Walking along the inward path and making attempts to realize the true essence is accompanied by both finding the ways of realizing personal spiritual trend in everyday life and also by the implementation of the choice made. Such labour of spirit is implemented by the transformation of the soul, new desires and feelings.

Thus, the theme of spirituality and spiritual development has always been the traditional one of religious thought, and also has become a new trend of secular science and scientific research in recent decades. Nowadays, materialists usually define spirituality as the highest level of personal development and self-regulation. The spiritual development of personality implies the process of self-awareness, the choice to consider spiritual guidelines and also willingness and readiness to act in accordance with these values. How can one get a sense of what direction to take following his/her spiritual path in this complicated world?

\section{Spiritual well-being}

The concept of "spiritual well-being" indicates not only the existence of specific spiritual state but it also implies that this state is a "blessing".

By "blessing" in the Russian language we usually mean something that can satisfy basic human needs and gives us a feeling of pleasure (See: "Explanatory dictionary of the Russian Language", ed. A.P. Evgenev, 1985). It is truly a positive value of the person or event (Kazakov, 2005). What is objectively good for a human being?

Medical research is aimed at identifying what is good for the human body. Psychologists are trying to answer the question what is good and what is not good for the mental life of a human being. Sociologists 
and lawyers are considering the welfare of man as a social being who operates in a social environment. Theologians have traditionally argued about spiritual benefits and are trying to find common points of view. However, the human individual is one whole being. All the spheres of his/her well-being are interrelated, they operate in a complex unity, and their balance and integrity are evaluated as individual's health.

Western psychologists strive to define "welfare" in broader sense as well-being, which is deemed as a multifaceted concept to represent the complex interplay of cultural, social, psychological, physical, economical and spiritual factors. The definition of health given by the World Health Organization employs the notion of "well-being" and adds elements that allow an individual to live a full life. Health as a state of well-being is deemed as an opportunity to realize his/her desires, to adapt to the environment and to be able to change it. Not only does man experience a state of well-being; he can also reflect on it. We consider "subjective well-being" as an evaluation component of personal attitude to himself/ herself and to life. This attitude includes both evaluation component and emotional component which embraces all spheres of life (material, social, mental and spiritual).

By going his/her spiritual path a person makes efforts to distinguish between what is "good" and what is not. Most world-wide religions direct a person in his/her individual development using spiritual guidelines. Eternal values can also refer to such guidelines of the spiritual path, and eventually they acquire a lot of personal meaning and become the basic motive and factor that regulates the individual's actions.

According to A. Maslow (1997), the supreme values are the truth, kindness, beauty, feeling of unity and struggle of opposites, diversity, perfection, simplicity, etc. Among them there are needs that have a great impact on the hierarchy of values in the course of inner growth and personal development when a person follows his/her spiritual path, which are as follows: (1) social need to live for other people and to do something for them; (2) cognizance needs (the need to know more about the surrounding world, about oneself and about the meaning of life and his/her life mission). One of the supreme values (also absolute spiritual values) is to perceive the truth that gives a person the feeling of inner freedom, gives an opportunity to make choices, promotes ability to make judgements that is the basis of inner life and is not subject to outer circumstances. 
The state of spiritual well-being is one of the states which a human being can experience on the path of his/her spiritual development and which correlate with all the other aspects of life. During this journey a person can have both victory and defeat. Each step in the direction of its spiritual essence is joy even if this motion is accompanied by sacrifice in other spheres of life. The feeling of joy indicates that a person approaches the satisfaction of basic human need - the need to be himself/ herself.

Such high level of spiritual well-being and health seems to be difficult to achieve because a person is usually in a constant state of choosing between the benefits of physical, social, mental, or spiritual values. A person has to create a system of values that might look supportive and he/she needs to learn how to act in accordance with it. However, individual perception of what is welfare and how to acheive it do not always coincide with those of the scientific knowledge about a human being.

\section{Spiritual illness}

Ignoring "the call for spiritual journey" (Campbell, 1997) and individual metamotives (Bratus', 1994), a person is deprived of something that is vital to his/her well-being. According to some experts, focus on the implementation of the supreme values, and using these values gives rise to fullness of life. Ignoring metaneeds can hamper the individual's development and create "metapathologies".

In his studies of physically healthy people A. Maslow discovered a number of "metapathologies" such as nihilism, a sense of meaningless of life, cynicism, distrust of others, a sense of isolation, alienation and estrangement, hopeless attitude toward the future, etc. Types of spiritual illness resulting from the loss of meaning of life are as follows: (a) existential vacuum (Rollo May's term for this type of illness is the devastation of soul); (b) noogenic neuroses (Victor Frankl thought they are caused by inability to solve spiritual problems or by finding a wrong way to deal with some spiritual issue, when a person starts acting contrary to the dictates of his/her conscience); (c) boredom that is deemed as some kind of a "graceless" state which usually stems from soulless leisure, laziness, idleness, gloom (an intrapsychic defense mechanism, a way of escaping from himself/herself); (d) "ontological shock" (fear, despair, hopeless- 
ness, associated with awareness of meaningless existence); (e) suicide (for existential or demonstrative reasons) as a tragic outcome of a spiritual catastrophe or moral distress.

Spiritual illness usually does not arise spontaneously. It emerges in the course of life as a consequence of ignoring the spiritual path or as a consequence of consuming "low quality spiritual food". Spiritual disadvantage is usually accompanied by feelings of physical, mental, or social distress accompanied by maladaptive and non-creative behaviour that does not contribute to making a "good" person.

\section{The role of values and beliefs in the regulation of behavior. Deviant behaviour as a consequence as a spiritual distress}

Constant transformations of human activity and combination of various types of activity give an opportunity to be quite flexible and to change its architecture in quest of beneficial results (Lavrova, Malaja, Orlov, \& Tvorogova, 1979). These transformations, and also the behaviour of the human individual in the so-called "crossroads" (such as motivational conflict, conflict of goals, prioritized actions, etc.) should be regulated so as not to generate chaotic behaviour. In such situations it is required from the individual to decide which kind of activity is prior, which step should be taken first, etc. This process is habitually regulated by thinking and intelligence.

However, it is the system of values and world outlook which is the most important for the human individual, since they influence the flow of our thoughts and feelings. This system "sheds light" on the path along which there occurs the thinking process. A person is really blessed to have the kind of personality that is mature and spiritually healthy and to have such a system of values where metavalues come to the fore.

Deviant behaviour that does not bring the person any benefits on the level of his/her true self, his/her essential characteristics is interconnected with spiritual crisis and lack of spiritual well-being (Mendelevich, 2001). Tobacco smoking is one of the examples of deviant behaviour. The data of recent clinical research show that it has the most negative impact on various aspects of human health, being harmful. According to our empirical research a student feels isolated in a group of fellow students because of poor communication skills (that could be 
a sign of lack of social well-being, which that student could be more or less aware of), and smoking can become a unique vehicle of establishing contacts with other people (Tvorogova, 1977). It mostly happens if some students, who have authority in the group, maintain smoking behaviour and there is the reference of this group to the isolated student. It is shown that the presence of smokers with high interpersonal status in the group promotes other students to develop positive attitude to smoking. If students are informed about the harm caused by smoking, but are not convinced that smoking is really as harmful for their health as people say, smoking becomes habitual and dependency persists. It is caused by the mere fact that good health is definitely not the main value in the hierarchy of values. Such behaviour is usually observed with those who are aware of the dangers of smoking, but they do not believe that it is really bad (for them advantages of smoking outweigh the possible disadvantages).

Moreover, the value of physical health is not included in the individual value system of these smokers as one of the key values (they are young, they feel that the time to start thinking about physical health has not come yet, in their life they find something more important than thinking about health) this value cannot control their everyday behaviour (which we used in the study of spiritual distress indicator). Thus, spiritual values are not the main ones for such a person. It has led us to the conclusion that smoking could be one of the indicators of insufficient spiritual well-being.

Smoking often becomes a vehicle of communication for isolated students. It helps them establish contacts with "the significant others" and give them the sense of "belonging". The survey of 1800 students of 13 universities in different cities and towns of the former Soviet Union showed the following important pattern - the period of study in high schools is critical for taking to smoking. Particularly at this stage the smoking dependency emerges. Among the graduates the number of male smokers was up to $90 \%$ and about $60 \%$ were females smokers (this research was carried out by N.D. Tvorogova with participation of I.G. Lavrova, E.V. Malaya, Y.M. Orlov (1979)).

In the study we have shown that the attempt to achieve social wellbeing (subjectively important for the surveyed age group) carried out by young smokers who experience disadvantage in the social sphere due to physical distress or poor health, leads to tobacco dependence (with 
ignorance of their spiritual values). In their value system social welfare is more important than physical and spiritual well-being, with the whole hierarchy of values transformed (Tvorogova, 2006).

\section{Factors that reduce the stability of people individuals to the effects of totalitarian sects and regimes}

Sincere aspiration for spiritual values, seeking satisfaction of transpersonal desires in society within which spiritual nihilism prevails (a loss of spiritual guidance proven by centuries) has lead mankind to consuming "spiritual surrogates" against the background of reduced levels of spiritual self-immunity. "Spiritual self-immunity" is deemed as a stable system of values where metavalues come to the fore and regulate human behaviour in everyday life.

"Spiritual surrogates", i.e. destructive religions, sects and regimes, is one of the possible sources of deviant behaviour (Volkov, 1996). Such cults are fundamentally different from others because of totalitarian and destructive nature of their activities, use of modern methods of manipulative impact on the person, suppression of autonomy, dependency formation (traditional religions hold sacred autonomy, privacy and creative identity, and see man as God's creation and thus endowed with the gift of a divine spark or divinity). J. Lifton was the first to describe the typical features of totalitarian cults.

Membership in a destructive cult is the result of two interacting factors: (1) the methods that are used by the members of this sect, and (2) the personal vulnerability of a potential recruit. Methods used by representatives of totalitarian sects are aimed to create a feeling of scarce and lack of spiritual well-being with a human individual, to prevent him/ her from following some really healthy path of spiritual growth, pious deeds, to break through his/her spiritual defense. Conversion to some faith looks more like seduction than the free choice of a person.

We consider exposure to a totalitarian cult (Tvorogova, 2002) as another sign of lack of spiritual well-being and "spiritual self-immunity". This could possibly be caused by a prolonged state of physical, mental, social disadvantage, or spiritual terrorism, which leads him/her to consume "spiritual food" of poor quality. Spiritual simplicity in a short distance can support short-term state of social welfare, comfortable state of 
mind that deceives a person, but in a long distance they often experience lack of spiritual well-being. They try to find a reason why they lack spiritual well-being. They believe that their own personal qualities and the behaviour of their former family, relatives and friends could cause this state of theirs. It is very rarely when a human individual becomes aware of the impact of both the "spiritual abuse" of the sect leaders and his/her own system of values and priorities. Loss of supreme spiritual values, blurring the boundaries between good and evil in society influence the level of both individual health, and the health of the entire nation. I.A. Gundarev (2008) reveals statistically relevant correlations between the level of high mortality of our population in the recent 10 years and the level of spiritual well-being of our society.

In 2006, a student of the Psychology Department of the Russian Academy of Education University, A.N. Kornakov, successfully defended his graduation thesis within which the basic models of mind control by destructive cults were studied (and which is done under the scientific guidance of Prof. N.D. Tvorogova). It is the third thesis work done under her scientific guidance in the recent five years. Mind control is defined as manipulation and forcible conversion of people to a faith (implantation of judgements) or behavior modification techniques without informing the person towards whom these techniques are used. The initiator of such impacts is trying to control human behaviour, thoughts and emotions and also the information they obtain. Gallup Institute (The American Institute of Public Opinion) offered a number of questions that help to understand whether the group is being under the control of consciousness (thoughts, feelings, behaviours).

Here are some of these questions: Is there any rigid hierarchy in the group? Are there any financial requirements that members of the group should meet? Do members of the group do anything under compulsion? What kind of relationship with the habitual social environment do members of the group have now, after they have joined the group? Are human right respected? What are the aims of the leaders of the group?

The subjects of A.N. Kornakov's empirical research were 36 nurses at the age of about 30 years old. He used V.A. Zhmurov's Method of Differential Diagnostic of Depressive States, E.K. Izard's Differential Emotion Questionnaire and others. The data show that most of the subjects experienced mind control. It happened more often when the potential victim was in a state of depression or experienced fear, disgust, grief, 
pain, guilt, remorse, anger (due to the blocking of significant needs, due to myocardial injury, forced to do something against their will).

The survey revealed that $80 \%$ of these nurses had contacts with representatives of totalitarian sects, $63 \%$ were invited to meetings and lectures conducted by members of these sects, two of them attended such meetings. It is also possible to experience mind control in everyday life ( $77 \%$ of the subjects say they experienced it at work, $11 \%$ experienced it at home), which affected the level of their depression and caused chronic fear.

We would like to make an assumption that spiritual well-being is crucial for prevention of identity of false piety, hit on an illusory way, proposed by representatives of totalitarian cults. It reduces individual's vulnerability to the effects of the latter. Individual health and availability of social support system on its path of healthy development is a means of prevention of the spiritual diseases.

Thus, we think that the study of spiritual component should be included into the framework of comprehensive research of public health.

\section{References}

Ball, G.A. (1997). Psikhologicheskoe soderzhanie lichnostnoj svobody: suschnost' i sostavljajuschie [Psychological content of personal freedom: the essence 'and components]. Psikhologicheskij zhurnal, 18(5).

Bratus', B.S. (1994). Psikhologija. Nravstvennost'. Kul'tura [Psychology. Morality. Culture]. Moscow: Menedzher, Rospedagenstvo. Kiev.

Campbell, J. (1997). Geroj s tysjach'ju licami [The Hero with a Thousand Faces].

Gundarev, I.A. (2008). Vlijanie duhovnoj atmosfery na zhiznesposobnost' naselenija [The influence of the spiritual atmosphere on the viability of the population]. In A.I. Vjalkova, Ju.M. Hrustaleva, \& V.D. Zhirnova (Eds.). Filosofija ukreplenija zdorov'ja nacii (pp. 116-124). Moscow: Rossijskoe filosofskoe obschestvo.

Kazakov, O.A. (2005). Pravoslavnaja jetika [Orthodox ethic]. St.-Petersburg: SATIS.

Lavrova, I.G., Malaja, Je.V., Orlov, Ju.M., \& Tvorogova, N.D. (1979). Nekotorye mediko-social'nye problemy dispanserizacii studentov [Some medico-social problems of medical examination of students ]. In Osnovnye napravlenija sovershenstvovanija ambulatorno-poliklinicheskoj pomoshi naseleniju [The main directions for improving outpatient care to the population]. Moscow: 1 MMI. 
Maslow, A. (1997). Psikhologija bytija [Psychology of Being]. Moscow: Vakler.

Mendelevich, V.D. (2001). Psikhologija deviantnogo povedenija [Psychology of deviant behavior ]. Moscow.

Tvorogova, N.D. (1977). Jeksperimental'noe izuchenie makrostruktury dejatel'nosti obschenija studenta [Experimental study of the microstructure of communicating student]: Avtoref. dis. ... kand. psikhol. nauk. Moscow.

Tvorogova, N.D. (2002). Povyshenie psikhologicheskoj ustojchivosti naselenija $\mathrm{k}$ vozdejstviju totalitarnyh sekt [Improving the psychological stability of the population to the effects of totalitarian sects]. In Tendencii $i$ perspektivy razvitija social'nopsikhologicheskoj pomoschi $v$ regione [Trends and prospects of social and psychological assistance in the region ]. Kazan'.

Tvorogova, N.D. (2006). Kurenie kak negativnyj jelement tehniki obschenija studenta [Smoking as a negative element of communication technology student]. Vestnik universiteta Rossijskoj akademii obrazovanija, 3.

Volkov, E.N. (1996). Prestupnyj vyzov prakticheskoj psikhologii: fenomen destruktivnyh kul'tov i kontrolja soznanija [Criminal challenge of practical psychology: the phenomenon of destructive cults and mind control]. Zhurnal prakticheskogo psikhologa, 2. 